\title{
Patnáct let Katedry manažerského účetnictví
}

\author{
Vážený čtenáŕi,
}

pokud předmluva předchozího čísla našeho časopisu byla věnována patnáctiletému výročí založení Fakulty financí a účetnictví Vysoké školy ekonomické v Praze, je přirozeným pokračováním připomenout i vznik fakultních pracovišt', která byla založena v souvislosti se vznikem fakulty a která $\mathrm{v}$ tomto roce též dosáhla plnoletosti. Mezi tato pracovišstě patří mimo jiné i katedra manažerského účetnictví, která vznikla rozdělením původní katedry účetnictví na katedru finančního a manažerského účetnictví dne 1. ledna 1991.

Dovolte, abych Vás v této souvislosti informoval nikoliv o minulosti katedry (pohled zpět nám totiž již z podstaty disciplíny, za jejichž rozvoj se cítíme odpovědní, není př́iliš blízký), ale spíše o její současnosti a budoucích záměrech.

\section{Studenti a studium}

Mezi důležité cíle ekonomických univerzit všude ve světě patří nejen seznámit všechny posluchače se základy účetnictví, ale také vychovávat odborníky, kteří ve své budoucí profesi budou vycházet z jeho dokonalé znalosti. Pracovníci katedry se v tomto smyslu snaží poskytnout „přidanou hodnotu“ svým studentům tím, že jim poskytuje vědomosti o tom, jak v roli tvůrce informačního systému - podniku koncipovat, resp. - v pozici manažera - využít informace manažersky orientovaného účetnictví a jak propojit tyto informační prưřezy se znalostí problematiky finančního řízení ekonomických subjektů.

Katedra se tedy ve svém hlavním pedagogickém zaměření orientuje na tu část účetních informací, kterou využívají pracovníci na různých úrovních podnikového vedení. Podstatným rysem těchto informací je úzké sepjetí účetních informací s dalšími hodnotovými informacemi, které se dnes chápou jako součást manažerského účetnictví (se systémem plánů a rozpočtů, s kalkulacemi výkonů a se systémem vnitropodnikových cen), ale také s informacemi o naturálním průběhu podnikatelského procesu. Tyto integrační vazby vyvolávají přirozenou nutnost zabývat se otázkami tvorby a využití manažerského účetnictví v kontextu celostně pojatého informačního systému firmy.

Základní obsahová náplň pedagogické činnosti katedry je tak obsahově strukturována do tř́ kurzů, které jsou v zásadě „osou“ vědomostního základu, který katedra poskytuje. Tuto osu tvoří

- kurz Manažerské účetnictví I, orientovaný v zásadě na obsah informací pro řízení podnikatelského procesu, o jehož parametrech již bylo $\mathrm{v}$ zásadě rozhodnuto, a na integritu vztahů mezi kalkulačním systémem, systémem plánů a rozpočtů, systémem vnitropodnikových cen a účetnictvím o vnitropodnikové struktuře,

- kurz Manažerské účetnictví II, orientovaný zejména na zjišt’ování, zpracování a využití informací pro rozhodování o budoucím průběhu podnikatelského procesu, a

- kurz Počítačem integrované řízení podniku, jehož cílem je koncepčně řešit otázky, související s úlohou účetních informací v automatizovaném podnikovém informačním systému. 
Na tuto základní osu pak navazují předměty a semináře, které výše uvedené průřrezy jednak rozvíjejí z hlediska zpo̊sobu zajištění, jednak je konkretizují pro různé typy podnikatelských subjektů. Sem patří zejména kurzy Exekutivní informační systémy, Praktika na počítači $z$ nákladového účetnictví a zejména pak kurz Strategicky orientované manažerské účetnictví, vyučovaný v české a anglické verzi, resp. systém seminářů věnovaný otázkám controllingu, moderním př́stupům řízení výkonnosti podnikatelských subjektů a využití informačních technologií v řízení podniků.

Katedra zajišt’uje svou výuku v drtivé většině vlastními učebními pomůckami, které se využívají ve výuce nejen na VŠE v Praze, ale i na dalších ekonomických fakultách v ČR a na Slovensku. Do budoucna si klademe jako základní cíl zvýšit pedagogickou účinnost těchto pomůcek, a to zejména budováním silnějších integračních vazeb základních učebních textů na multimediální pomůcky a rozšířením výuky budované na aplikaci př́ípadových studií.

\section{Vědecko-výzkumné aktivity}

Výše uvedeným pedagogickým záměrům odpovídá i primární vědecko-výzkumná orientace katedry, která je již tradičně a dlouhodobě strukturována formou dílčích úkolů, které jsou řešeny pod integrujícím názvem Tvorba a využití manažersky orientovaných informačních systémů. V rámci tohoto základního zaměření se členové katedry v posledních zaměřují zejména na následující problémové oblasti:

- Role controllingu a manažerského účetnictví v integraci podnikového řízení,

- Moderní prŕstupy měření výkonnosti podniku s využitím účetních informací,

- Strategické řízení podniku a jeho informační zajištění

- Využití účelového členění nákladů a informace podle segmentů pro kvantifikaci vrcholového kritéria ekonomického subjektu.

V dlouhodobém výhledu spatřuje nicméně katedra prioritu v zajištění požadavků, které plynou $\mathrm{z}$ řešení výzkumného záměru fakulty Rozvoj finanční a účetní teorie z interdisciplinárního hlediska. V rámci tohoto grantu již v roce 2005 katedra uspořádala národní konferenci na téma „Moderní prŕstupy řízení výkonnosti a jejich informační podpora“. Ve vazbě na tuto tradici pak byla pak v zář́ 2006 také hlavním organizátorem mezinárodní konference „Progresivní změny v systémech řízení výkonnosti“, jejímiž účastníky byli mimo jiné zástupci dvou nejvýznamnějších controllingových škol prof. Horváth a doc. Hofmann, generální a finanční ředitelé společností GiTy, Papirius, NextiraOne, Sudop Invest a další významní odborníci. Celkově se této konference zúčastnilo cca 150 přednášejících a posluchačů.

Kromě pokračování této tradice je hlavním záměrem katedry do budoucna rozšířit znalost českého podnikatelského prostředí na bázi empirických výzkumů a integrovat tyto poznatky zejména s obdobně koncipovanými výzkumy, probíhajícími v zemích EU.

\section{Zahraniční vztahy}

Mezi důležité aktivity vysokoškolských pracovišt' patří i budování zahraničních vztahů. Ani ty nejsou nijak úzké; členové katedry se napřr.

- významně podílejí se na přípravě učebních pomůcek, výuce a prrípravě zkoušky z manažerského účetnictví v rámci projektu certifikace a vzdělávání Svazu účetních, 
který byl zpracován pod obsahovou garancí britské Asociace autorizovaných účetních (Association of Chartered Certified Accountants - ACCA);

- spolupracují na pedagogických aktivitách Francouzsko-českého institutu, který vyvíjí svou činnost při VŠE v Praze;

- aktivně podíleli na organizační a obsahové přípravě 27. výročního kongresu Evropské účetní asociace (European Accounting Association - EAA), který proběhl na počátku dubna 2004 na VŠE v Praze a také pravidelně prezentují výsledky svých vědeckých aktivit na výročních kongresech EAA,

- pravidelně prezentují s cyklem přednášek v rámci výměnných pobyti̊ hostujících profesorů, konkrétně na univerzitě v Paříži (Sorbonne-Pahtheon) a univerzitě v Lyonu.

\section{Vztahy s praxí}

Členové katedry si jsou také vědomi, že pokud chtějí výrazněji ovlivňovat rozvoj účetní profese, musí své vědecké i pedagogické aktivity realizovat ve spolupráci nejen s kolegy z VŠE a s reprezentanty progresivní podnikové praxe, ale i v úzkém kontaktu s vládními a profesními institucemi. Ani v tomto směru nejsou aktivity pracovníků katedry zanedbatelné. Katedra

- obsahově garantuje a zajišt'uje výuku kurzů Finanční účetnictví a Manažerské účetnictví na Pražské mezinárodní manažerské škole při Vysoké škole ekonomické v Praze;

- se významně podílí na vzdělávání před vstupem do profese a na přípravě zkouškových zadání na Komoře auditorů České republiky; mimochodem - na katedře aktivně působí čtyři auditoři zapsaní v seznamu auditorů Komory auditorů České republiky;

- má své zastoupení v nejvyšším výkonném orgánu (Radě) a ve Výboru pro auditorské zkoušky Komory auditorů a v Radě a Komitétu pro certifikaci a vzdělávání - dvou nejvyšších orgánech Svazu účetních;

- podílí se na obsahové garanci a výuce mezinárodně certifkovaných controllerů, kterou organizačně zajištuje společnost Controller Institut - Contrast Consulting, s. r. o. Praha;

- je zastoupena $v$ redakční radě časopisu Účetnictví a renomovaného odborného periodika Verlag Dashofer;

- se podílí formou připomínkového řízení na tvorbě legislativních norem, vytvářejících právní rámec pro rozvoj profese, zejména na tvorbě zákona o účetnictví a zákona o auditorech.

Spolupráce s katedrou finančního účetnictví prolíná pak i do výuky na kurzech celoživotního vzdělávání, kde členové katedry manažerského účetnictví - kromě svého samostatného dvousemestrálního „Využití účetních informací v řízení podniku“ (v listopadu 2006 byl zahájen již 5. běh tohoto kurzu) participují na obsahové garanci a výuce kurzu celoživotního vzdělávání katedry finančního účetnictví „Mezinárodně uznávané účetní standardy“.

\section{Závěrem}

Katedra manažerského účetnictví patři mezi malé katedry; proto se snaží kvalitativně rozvíjet zejména spoluprací s významnými odborníky z praxe, kteří působí na katedře formou dílčích úvazků, a výchovou „vlastních“ odborníků, a to zejména formou interního 
doktorandského studia. Vzhledem $\mathrm{k}$ tomu, že na katedře pracuje řada pracovníků formou dílčího úvazku, podílí se tak aktivně na její činnosti celkem 13 odborníků.

Samozřejmě - máme i své problémy. Nedaří se nám oslovovat velký počet studenti̊ svými tématy diplomových prací. Kurzy katedry jsou obecně charakterizovány ve studentské anketě jako nadprůměrně obtížné a ne vždy se je daří přiblížit studentům takovými formami, které by je učinily přitažlivější a pochopitelné.

Zejména z tohoto důvodu si katedra vytkla jako nejbližší úkol zvýšit povědomí o svých aktivitách nejen $\mathrm{v}$ očích odborné veřejnosti, ale hlavně mezi studenty.

prof. Ing. Bohumil Král, CSc.

člen redakční rady Českého finančního a účetního časopisu

a vedoucí Katedry manažerského účetnictví,

Fakulta financí a účetnictví

Vysoká škola ekonomická v Praze 